\title{
Analiza problemów tłumaczeniowych przekładu konstytucji Grecji na język polski
}

\section{The Analysis of Translation Problems Occurring in the Translation of the Greek Constitution into Polish}

\author{
Natalia Ciesielczyk \\ INSTYTUT JĘZYKOZNAWSTWA, UNIWERSYTET IM. ADAMA MiCKIEWICZA \\ AL. NiEPODLEGŁOŚCI 4, 61-874 POZNAŃ \\ nataliaciesielczyk@gmail.com
}

\begin{abstract}
The subject of this article is the analysis of problems in the translation of the Greek Constitution into Polish which was published by the Publishing House of the Polish Parliament (Wydawnictwo Sejmowe) in 2005. This text was not translated directly from Greek but from its French and English versions. I attempt to prove that this is the main reason why it contains so many incorrect translations, presenting a selection of classified mistakes found in the Polish text and comparing them with analogical parts of the Greek original text as well as of its French and English versions. I give also some suggestions of correct Polish equivalents for a number of Greek legal terms used in the text of the Greek Constitution.
\end{abstract}

\section{Wstęp}

Tłumaczenie tekstów sformułowanych w języku prawnym (do których zalicza się tekst konstytucji) oraz prawniczym różni się od przekładu innych tekstów specjalistycznych tym, że nie polega ono wyłącznie na tłumaczeniu tekstu na poziomie językowym, ale na porównywaniu dwóch systemów prawnych (Schroth 1986: 53). Ma ono wybitnie multidyscyplinarny charakter, który objawia się w jego związku nie tylko z językoznawstwem, ale również $\mathrm{z}$ kulturoznawstwem i komparatystyką prawniczą. Bez wahania można uznać przekład prawniczy, który jest działaniem niezwykle złożonym i wymaga od tłumacza kombinacji wielu umiejętności oraz bardzo szerokiej wiedzy, za najtrudniejszy gatunek tłumaczenia specjalistycznego (Manganaras 1996: 14-15).

Przekład tekstów z zakresu prawa sprawia tłumaczowi trudności w sensie językowym, ale nade wszystko w sensie interpretacyjnym. W celu przetłumaczenia tekstu sformułowanego $\mathrm{w}$ języku prawnym lub prawniczym należy nie tylko odnaleźć znaczenie wyrazów, ale przede wszystkim zrozumieć sens, jaki autor tekstu, np. w przypadku konstytucji ustawodawca, rzeczywiście chciał nadać swojemu tekstowi. Przekład taki wymaga od tłumacza znajomości zarówno systemu prawnego języka źródłowego, ponieważ komunikat w nim zawarty nadany 
jest za pomocą kodu, którego rozszyfrowanie wymaga rozważenia kilku możliwych interpretacji prawnych, jak i systemu prawnego języka docelowego, co umożliwia ponowne, poprawne zakodowanie komunikatu (Pieńkos 1999: 120-121). Jednak, pomimo wielu trudności, tego rodzaju tłumaczenia stanowią znaczą część wszystkich obecnie dokonywanych przekładów.

Zwłaszcza w czasach coraz bardziej intensywnej integracji europejskiej, znaczenie tłumaczenia tekstów prawnych i prawniczych gwaltownie wzrasta. Teksty tego typu funkcjonują w realiach Unii Europejskiej we wszystkich dwudziestu trzech jej językach urzędowych, jako że zarówno państwa członkowskie, jak i ich obywatele mogą zwracać się do instytucji wspólnotowych w dowolnym języku urzędowym, czyli w każdym języku państwa członkowskiego, zaś instytucje te są obowiązane udzielić im odpowiedzi w tym samym języku (JopekBosiacka 2006: 173). W konsekwencji często zachodzi potrzeba dokonania tłumaczenia pomiędzy dwoma rzadkimi językami (taką parę stanowią np. języki polski i grecki). Niestety takich tłumaczeń zazwyczaj nie dokonuje się bezpośrednio z oryginału, ale poprzez języki pośrednie (langue pivot), którymi są najczęściej języki angielski $\mathrm{i}$ francuski, choć powszechnie wiadomo, iż tłumaczenie $\mathrm{z}$ tłumaczenia jest bardzo ryzykownym przedsięwzięciem i może prowadzić do powstania dużej liczby błędów w tekście przekładu (Matulewska, Nowak 2006: $38)$.

Celem niniejszego artykułu jest zwrócenie uwagi na ten problem, poprzez wskazanie i omówienie licznych nieścisłości w przekładzie konstytucji Grecji na język polski. Uważam, że przyczyną pojawienia się zdecydowanej większości błędów w tym tekście jest fakt, iż podstawą jego tłumaczenia nie był bezpośrednio grecki oryginał, ale jego wersje francuska i angielska. Postaram się tego dowieść, przeprowadzając analizę porównawczą tekstu konstytucji Grecji w czterech wersjach językowych:

$>$ polskiej: Konstytucja Grecji ${ }^{1}$,

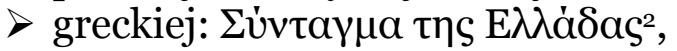

$>$ francuskiej: Constitution de la Grèces,

$>$ angielskiej: The constitution of Greece4.

Zanim jednak rozpocznę ich analizę, chciałabym omówić pokrótce kontekst historyczny oraz treść zarówno oryginalnego tekstu greckiej konstytucji, jak i jego przekładu na język polski.

\section{Konstytucja Grecji}

Konstytucja Grecji, której tłumaczenie na język polski analizuję w niniejszym artykule, została uchwalona w 1975 roku. Zanim jednak mogło do tego dojść, w Grecji należało odtworzyć demokrację po siedmiu latach rządów „czarnych pułkowników". Od 1967 roku w państwie tym obowiązywało ustawodawstwo stanu wyjątkowego, zawieszone były prawa obywatelskie i zdelegalizowane partie polityczne. Junta upadła w lipcu 1974 roku i wtedy do sformowania nowego,

${ }^{1}$ Konstytucja Grecji. 2005. Tłumaczenie: G. i W. Uliccy, B. Zdaniuk.

2 http://www.parliament.gr/pdf/syntagmaHanatheoritikiVouli.pdf

3 http://www.parliament.gr/english/pdf/o01-180\%20galliko.pdf

$4 \mathrm{http}: / /$ www.parliament.gr/english/pdf/oo1-156\%20aggliko.pdf 
cywilnego rządu powołano przebywającego dotąd w Paryżu Kostasa Karamanlisa, który pełnił już funkcję premiera Republiki Grecji w latach 1958 - 1963 (Bonarek, Czekalski, Sprawski, Turlej 2005: 616-617, 620).

Karamanlis powołał po powrocie do Grecji tymczasowy Rząd Jedności Narodowej. Jednak, by naprawdę przywrócić rządy demokratyczne, konieczne było jak najszybsze przeprowadzenie wyborów parlamentarnych. Odbyły się one 17 listopada 1974 roku i przyniosły zdecydowane zwycięstwo partii K. Karamanlisa

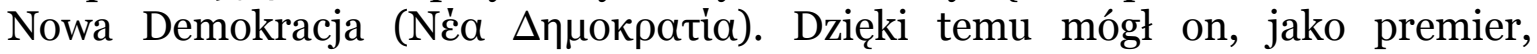
przeprowadzać wszelkie zmiany konstytucyjne. Zanim jednak rozpoczęto prace nad nową konstytucją, należało uregulować jeszcze jedną kwestię, a mianowicie przeprowadzić referendum w sprawie ustroju państwa. Miało ono zasadnicze znaczenie, jako że przed wprowadzeniem rządów pułkowników Grecja była monarchią konstytucyjną. Jednak, zgodnie z oczekiwaniami, 8 grudnia 1974 roku zdecydowana większość Greków opowiedziała się za ustrojem republikańskim (Brzeziński 2002: 189).

Już w styczniu 1975 roku rząd Karamanlisa złożył w parlamencie projekt nowej ustawy zasadniczej. Po kilku miesiącach prac Komisji Konstytucyjnej nowa konstytucja Grecji została uchwalona jednogłośnie przez grecki parlament 7 czerwca, a weszła w życie dnia 11 czerwca 1975 roku i obowiązuje do dziś. Do chwili obecnej była ona trzykrotnie nowelizowana: w 1986, w 2001, a także w 2008 roku jednak wprowadzone wówczas liczne poprawki nie zmieniły ustanowionych $\mathrm{w}$ pierwotnej wersji konstytucji zasad ustrojowych państwa (Пoúخnৎ 2002: 67).

Konstytucja z 1975 roku stwierdza, że Grecja jest republiką parlamentarną.

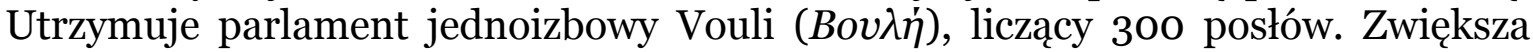
jednak znacznie uprawnienia władzy wykonawczej. Prezydent, wybierany przez parlament, ma m.in. prawo mianowania premiera, rozwiązywania parlamentu, a także zawetowania każdej ustawy, która nie uzyskała 3/5 głosów w Boviń (Bonarek, Czekalski, Sprawski, Turlej 2005: 630). Prezydent reprezentuje państwo w stosunkach międzynarodowych, może wypowiadać wojny oraz zawierać traktaty pokojowe i sojusze.

Jednak nie tylko zmiany o charakterze ustrojowym stanowią o wielkiej wadze greckiej konstytucji z 1975 roku. Niezwykle ważna jej część obejmuje postanowienia dotyczące praw jednostki i społeczeństwa. Konstytucja ta gwarantuje równość wobec prawa wszystkich obywateli, a w związku z tym takie same prawa i obowiązki dla mężczyzn i kobiet w zakresie uczestniczenia w życiu społecznym, ekonomicznym oraz politycznym kraju. Nikt nie może być bezprawnie ścigany, aresztowany bądź uwięziony, co zapewnia prawo do wolności osobistej. Ponadto omawiana tu konstytucja ustanawia wolność sumienia i wyznania, jak również wolność słowa oraz swobodę tworzenia i funkcjonowania partii politycznych i związków zawodowych (Brzeziński 2002: 190).

Dla Greków niezwykle istotny jest również fakt, iż, w przeciwieństwie do poprzedniej konstytucji Grecji z 1952 roku, konstytucja z roku 1975 nie zawiera przepisu, ustanawiającego archaizujący język katharevousa ( $\kappa \alpha \theta \alpha \rho \varepsilon v ́ o v \sigma \alpha$ ) greckim językiem urzędowym. Dzięki temu, otworzyła ona drogę kolejnym ustawom, które wprowadziły do szkół i urzędów język nowogrecki oparty na języku

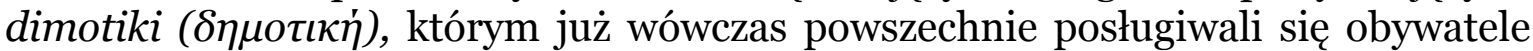
Grecji. Warto jednak zauważyć, że tekst konstytucji został sporządzony w języku $\kappa \alpha \theta \alpha \rho \varepsilon v ́ o v \sigma \alpha$ i dopiero przy okazji nowelizacji w 1986 roku przełożono go na język

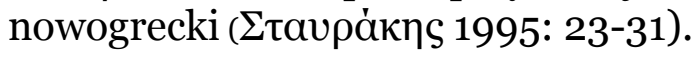


Tłumaczenie konstytucji Grecji na język polski zostało dokonane w większej części przez Grażynę i Włodzimierza Ulickich, a zmiany wprowadzone na mocy rewizji z 2001 roku przełożył Bartłomiej Zdaniuk. Jak wcześniej wspomniałam, tłumacze ci nie korzystali w swojej pracy z oryginalnego tekstu w języku greckim, ale $\mathrm{z}$ jego francuskiej i angielskiej wersji. Analizowana w niniejszym artykule wersja tłumaczenia została opublikowana w 2005 roku przez Wydawnictwo Sejmowe w serii Konstytucje jako wydanie drugie zmienione i uaktualnione. Pierwsze wydanie Konstytucji Grecji w Polsce miało miejsce w 1992 roku.

Odnośnie struktury konstytucji z 1975 roku składała się ona ze stu dwudziestu artykułów. Obecnie, po trzech nowelizacjach w 1986, 2001 oraz 2008 roku, podczas których dodano między innymi artykuły 5A, 9A, 100A i 101A i uchylono art. 39, tekst konstytucji Grecji składa się ze stu dwudziestu trzech artykułów (Kamiński 2004: 15-16). W analizowanym przeze mnie w niniejszej pracy tłumaczeniu konstytucji Grecji na język polski pominięto jej postanowienia przejściowe, do których w oryginale zaliczają się artykuły 111 - 119. Przekład ów składa się zatem ze stu czternastu artykułów, co stanowi około 3,5 arkusza wydawniczego.

Warto zauważyć, że Konstytucja Grecji została opublikowana w języku polskim przed jej ostatnią nowelizacją z 2008 roku - dlatego podczas analizy tłumaczenia nie uwzględniłam nieścisłości wynikających ze zmian wówczas wprowadzonych.

\section{Analiza przekładu}

Analizując przekład konstytucji Grecji na język polski i zestawiając poszczególne jego fragmenty zarówno $\mathrm{z}$ greckim oryginałem, jak i $\mathrm{z}$ tekstami $\mathrm{w}$ języku francuskim oraz angielskim, napotkałam zaskakująco dużo błędów i nieścisłości. W celu ich omówienia, wybrałam spośród bogatej literatury przedmiotu, najwłaściwszą w tym przypadku klasyfikację błędów występujących w przekładzie, którą przedstawię poniżej, ilustrując ją odpowiednimi przykładami odnalezionymi w analizowanym tekście tłumaczenia.

Zdaniem J. Delisle oraz pozostałych autorów książki Terminologia thumaczenia wszystkie istotne nieprawidłowości spotykane w przekładzie powstają $\mathrm{w}$ wyniku popełniania przez tlumaczy błędów metodologicznych. Wynikają one z:

> niezastosowania przez tłumacza właściwych zasad tłumaczenia, reguł i technik tłumaczeniowych; do tego typu błędów należą m.in. zbyt pobieżna analiza całego kontekstu, nadmierne stosowanie kalek językowych, tłumaczenie zdanie po zdaniu, bez wzięcia pod uwagę spójności globalnej tekstu itd.

> niezastosowania odpowiednich praktyk translatorskich; do tego typu błędów należy np. zbyt pobieżna analiza właściwej dokumentacji, wadliwe posługiwanie się słownikami, brak końcowej weryfikacji poprawności tekstu przekładu oraz, co jest najbardziej istotne dla niniejszej pracy, poszukiwanie odpowiedników terminologicznych w tekstach, które już są tłumaczeniami z innego języka (co miało miejsce $\mathrm{w}$ tłumaczeniu analizowanego tu przeze mnie tekstu konstytucji Grecji na język polski, które zostało dokonane z języka francuskiego i angielskiego, a nie bezpośrednio z języka greckiego).

Omówione powyżej błędy metodologiczne mogą prowadzić do powstania $\mathrm{w}$ tekście przekładu błędów językowych oraz błędów tłumaczeniowych (Delisle, LeeJahnke, Cormier 2004: 29). Pierwsze $\mathrm{z}$ nich są widoczne dla rodzimego 
użytkownika języka polskiego nawet bez porównywania tekstu przekładu z tekstem oryginału, natomiast drugie wykrywa się właśnie w drodze takiego porównania. Charakter błędów językowych i tłumaczeniowych różni się, tak samo jak przyczyny ich powstawania (Nowak 2006: 173).

\subsection{Błędy tłumaczeniowe}

Błędy tłumaczeniowe, które w niniejszym artykule omówię zgodnie z klasyfikacją sporządzoną przez A. Pisarską i T. Tomaszkiewicz w książce Wspótczesne tendencje przekładoznawcze, wynikają z braku odpowiedniej wiedzy na temat zasad przekładu oraz nieznajomości lub wadliwego zastosowania technik tłumaczeniowych, ale także $\mathrm{z}$ niewiedzy tłumacza na poziomie językowym lub na poziomie znajomości dziedziny, do której należy tekst źródłowy, co powoduje jego złą interpretację.

Za jeden z rodzajów błędów tłumaczeniowych A. Pisarska i T. Tomaszkiewicz uznają interferencję między dwoma językami. Może ona zachodzić na wielu poziomach: morfologicznym, leksykalnym, składniowym, stylistycznym i kulturowym, a polega na zastosowaniu w tekście przekładu formy językowej, charakterystycznej dla języka źródłowego. Opisując zjawisko interferencji autorki wymieniają dwa jej rodzaje:

- Fałszywi przyjaciele (faux-amis, false friends) są to słowa w dwóch językach, które z punktu widzenia morfologicznego są podobne, często mają podobną ortografię i wymowę, ale ich znaczenia różnią się; tłumacz, sugerując się ich podobieństwem, może automatycznie zastąpić jeden wyraz drugim, zmieniając tym samym sens przekładanego tekstu (Pisarska, Tomaszkiewicz 1998: 158).

Przykład 1:

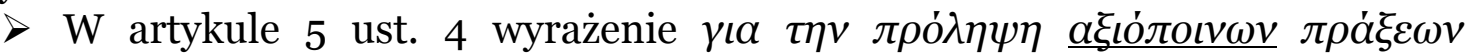
przetłumaczono jako: $w$ celu zapobieżenia czynom kryminalnym, co jest kalką francuskiego pour prévenir des actes criminels, bądź angielskiego in order to prevent the commitment of criminal acts. Zgodnie $\mathrm{z}$ m.in. art. $1 \S 1$ polskiego Kodeksu Karnego5 to wyrażenie powinno brzmieć następująco: $w$ celu zapobieżenia czynom zabronionym.

Przykład 2:

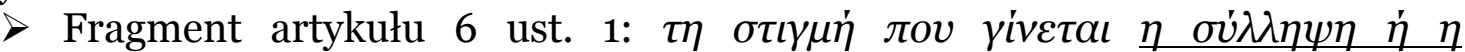

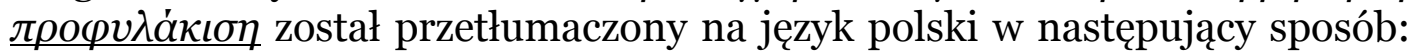
$w$ momencie aresztowania lub zatrzymania tymczasowego, pod wpływem wersji francuskiej: au moment de l'arrestation ou de la mise en détention provisoire, bądź angielskiej: at the moment of arrest or detention pending trial. Zgodnie m.in. $\mathrm{z}$ rozdziałem XV polskiego Kodeksu Karnego Wykonawczego ${ }^{6}$ fragment ten powinien brzmieć: $w$ momencie zatrzymania lub aresztowania tymczasowego.

Przykład 3:

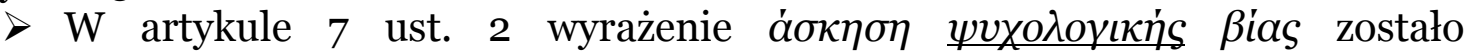
przetłumaczone jako: presja psychologiczna pod wpływem francuskiego

5 Ustawa z dnia 6 czerwca 1997 r. - Kodeks karny.

6 Ustawa z dnia 6 czerwca 1997 r. - Kodeks karny wykonawczy. 
contrainte psychologique, bądź angielskiego psychological violence. $\mathrm{W}$ języku polskim wyrażenie to powinno brzmieć następująco: stosowanie Przykład 4: przemocy psychicznej.

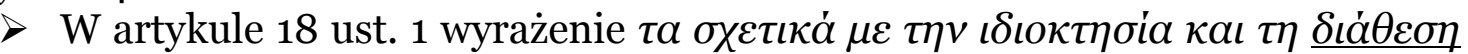
$\tau \omega \nu \mu \varepsilon \tau \alpha \lambda \lambda \varepsilon i \omega v$ zostało przetłumaczone jako: kwestie dotyczące wlasności $i$ udzielania koncesji na kopalnie pod wpływem francuskiego les matières concernant la propriété et la concession des mines. W języku polskim wyrażenie to powinno brzmieć następująco: kwestie dotyczące własności $i$ dysponowania kopalniami.

Warto zwrócić uwagę na fakt, że w artykule 18 ust. 6 podobne wyrażenie: $\tau \alpha$

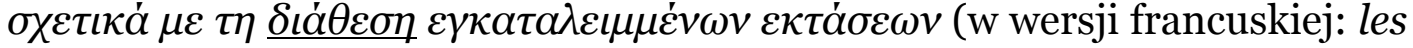
matières concernant la concession des terres vacantes) zostało przetłumaczone poprawnie jako: dysponowanie opuszczonymi gruntami.

Podobny błąd popełniono $\mathrm{w}$ artykule 36 ust. 2, w którym wyrażenie oı

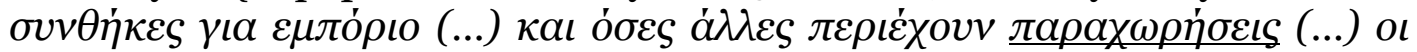

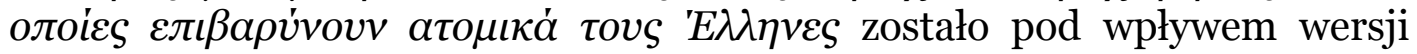
francuskiej (Les traités de commerce (...) ainsi que ceux qui comportent des concessions (...) qui grèvent individuellement les Hellènes) przetłumaczone następująco: umowy dotyczące handlu (...) oraz wszystkie umowy dotyczace udzielania koncesji (...), jak również umowy nakładające indywidualne obciążenia na Greków. W tym przypadku błąd ten spowodował nieścisłość w dalszej części zdania. W tekście greckim zaimek oı

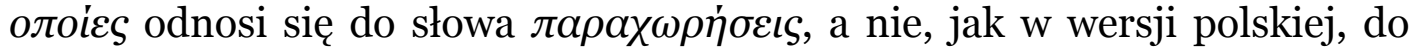
słowa $\sigma v v \theta \dot{\eta} \kappa \varepsilon s$. Zatem prawidłowe tłumaczenie tego wyrażenia brzmi następująco: umowy dotyczące handlu (...) oraz wszystkie umowy zawierajace ustepstwa, w wyniku których nakładane sq na Greków indywidualne obciążenia.

Przykład 5:

> W artykule 18 ust. 4 wyrażenie o $\alpha v \alpha \delta \alpha \sigma \mu o ́ s ~ \alpha \gamma \rho o \tau \iota \kappa \omega ́ v ~ \varepsilon \kappa \tau \dot{\alpha} \sigma \varepsilon \omega v$ zostało przetłumaczone jako: komasowanie terenów rolnych pod wpływem francuskiego: le remembrement des terrains agricoles. Tymczasem wg Słownika Języka Polskiego PWN 7 prawidłowa kolokacja brzmi: komasowanie gruntów rolnych.

Przykład 6:

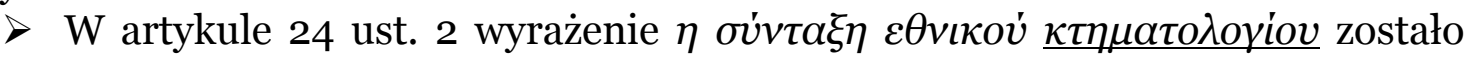
przetłumaczone jako: sporządzenie krajowego spisu kadastralnego pod wpływem francuskiego la rédaction d’un cadastre national, bądź angielskiego the compilation of a national cadastre. Tymczasem według Słownika Języka Polskiego PWN8 taki spis nosi nazwę kataster, a utworzony od niego przymiotnik to katastralny. W konsekwencji tłumaczenie owego wyrażenia powinno brzmieć następująco: sporządzenie krajowego rejestru katastralnego. 
- Anglicyzmy, germanizmy, galicyzmy, itd. są to zapożyczenia z języków obcych na poziomie morfologicznym, leksykalnym, semantycznym lub składniowym, z których część zintegrowała się z językiem docelowym, a część jest uważana za błędne, jako że nie odpowiadają normom języka przekładu (w analizowanym tłumaczeniu greckiej konstytucji na język polski odnalazłam dwa przykłady galicyzmów, jako że podstawą tego przekładu był głównie tekst francuski) (Pisarska, Tomaszkiewicz 1998: 159).

Przykład 1:

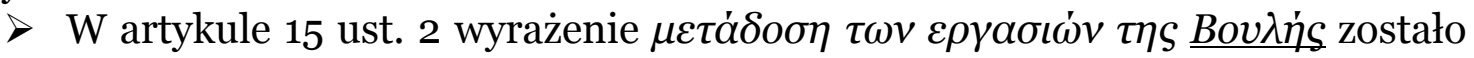
przetłumaczone jako: transmisji (...) prac Izby Deputowanych pod wpływem wersji francuskiej: la retransmission (...) des travaux de la Chambre des députés. Według Słownika Języka Polskiego PWN9 Izba Deputowanych oznacza niższą izbę parlamentu w niektórych państwach. Jako że w Grecji parlament jest jednoizbowy, wyrażenie to powinno się przetłumaczyć następująco: transmisji prac Parlamentu.

Przykład 2:

Błąd ten powtarza się wielokrotnie w analizowanym tu przekładzie.

$>\mathrm{W}$ artykule 27 ust. 1 oraz 27 ust. 2 wyrażenie $\mu \varepsilon \tau \eta v \alpha \pi \dot{\lambda} \lambda v \tau \eta \lambda \lambda \varepsilon ı \psi \eta \varphi i \alpha$

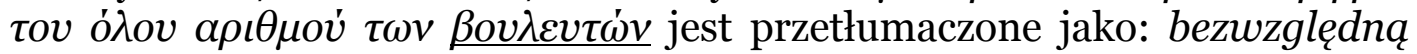
większościa glosów ogólnej liczby deputowanych pod wpływem wersji francuskiej: à la majorité absolue du nombre total des députés. Według Słownika Języka Polskiego PWN10 słowo deputowany oznacza członka niższej izby parlamentu $\mathrm{w}$ niektórych krajach (np. we Francji). $\mathrm{Z}$ tego względu uważam, że wyrażenie to powinno się tłumaczyć z języka greckiego jako: bezwzględnq większościa głosów ogólnej liczny parlamentarzystów. Również ten błąd powtarza się wielokrotnie w analizowanym tu przekładzie.

Warto w tym miejscu zwrócić uwagę również na zjawisko kalkowania, tj. na technikę thumaczeniową polegającą na odwzorowaniu struktury semantycznej lub formalnej jednostki innego języka. Nadmierne stosowanie tej techniki także jest uważane za błąd, którego powodem jest interferencja. Kalki językowe dzielą się na:

- kalki semantyczne, które polegają na nadaniu jednostce leksykalnej danego języka nowego znaczenia pod wpływem języka obcego (w analizowanym przekładzie nie znalazłam żadnego przykładu kalki semantycznej),

- kalki strukturalne, tj. wyrazy bądź wyrażenia danego języka odwzorowujące strukturę języka obcego (Lukszyn 1993: 147-148).

Przykład 1:

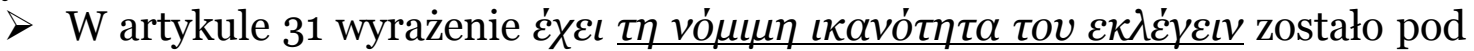
wpływem języka francuskiego (possède le droit de vote) przetłumaczone jako: ma prawo glosowania. Wyrażenie to ma ten sam sens co w oryginale, jednak pod względem strukturalnym jest kalką z języka francuskiego. Poprawne tłumaczenie tego wyrażenia na język polski powinno brzmieć następująco: posiada czynne prawo wyborcze. 


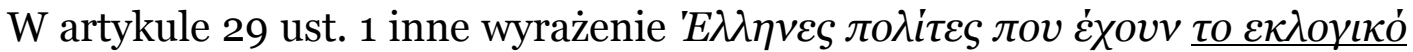

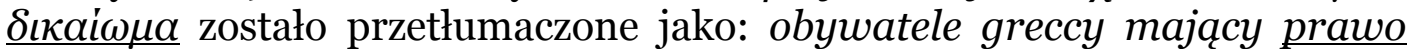
głosowania, znów pod wpływem wersji francuskiej: les citoyens hellènes ayant droit de vote. Tymczasem słownik języka greckiego podaje, że wyrażenie $\varepsilon \kappa \lambda o \gamma \iota \kappa o ́ ~ \delta ı \kappa \alpha i ́ \omega \mu \alpha$ zawiera w sobie znaczenie zarówno czynnego, jak i biernego prawa wyborczego ( $\varepsilon \kappa \lambda \dot{\varepsilon} \gamma \varepsilon \sigma \theta \alpha \iota){ }^{11}$. Zatem powyższe wyrażenie należałoby przetłumaczyć następująco: obywatele greccy majacy prawo wyborcze. W tym przypadku zastosowanie kalki strukturalnej $\mathrm{z}$ języka francuskiego zmieniło sens oryginału.

Warto zauważyć, że w kolejnym zdaniu tego samego ustępu wyrażenie

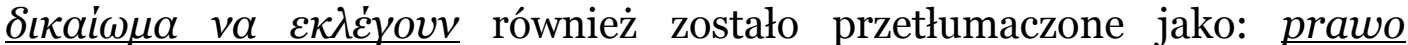
głosowania. Tym razem, tak jak w pierwszym przypadku, sens obu wyrażeń jest taki sam, choć z punktu widzenia polskiego prawodawstwa ${ }^{12}$ wyrażenie to powinno zostać przetłumaczone jako: prawo wybierania.

Bardzo poważnymi błędami tłumaczeniowymi są według A. Pisarskiej i T. Tomaszkiewicz nieprawidłowości wynikające $\mathrm{z}$ niezrozumienia, które powstają $\mathrm{w}$ przypadku, gdy tłumacz nie zrozumie intencji autora tekstu oryginału. Może się to zdarzyć np. jeśli nie zna on pewnych elementów leksykalnych lub struktur gramatycznych, realiów kultury języka źródłowego bądź, w przypadku tekstów specjalistycznych, dziedziny, do której należy tłumaczony tekst (Pisarska, Tomaszkiewicz 1998: 159-160). Istnieją trzy kategorie błędów wynikających z niezrozumienia:

- Sens fałszywy (znaczenie fałszywe) polega na przypisaniu pewnemu słowu lub wyrażeniu tekstu źródłowego niewłaściwego znaczenia leksykalnego, co zmienia sens danego tekstu, ale nie prowadzi do znaczenia kompletnie przeciwnego. Ta nieprawidłowość wynika najczęściej ze złej interpretacji znaczenia kontekstowego danego słowa i jest mniejszym błędem niż sens przeciwny czy nonsens, ponieważ nie zmienia całkowicie sensu tekstu źródłowego.

Przykład 1:

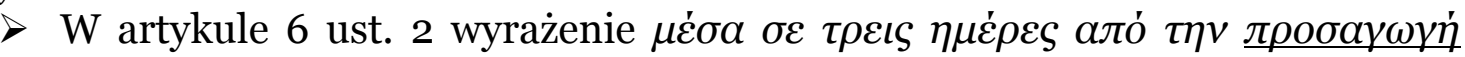
zostało zgodnie z wersją francuską (dans les trois jours qui suivent la comparution) przetłumaczone jako: $w$ ciagu 3 dni od stawienia sie zatrzymanego $w$ sadzie, co zmienia sens greckiego oryginału, którego tłumaczenie powinno brzmieć: $w$ ciagu 3 dni od doprowadzenia zatrzymanego przed sąd.

Przykład 2:

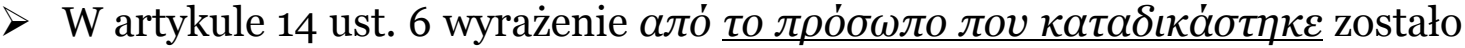
przetłumaczone na język polski jako: przez oskarżonego, choć w wersji

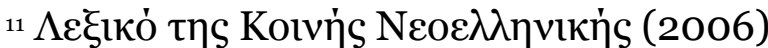

${ }^{12}$ np. Ustawa z dnia 27 września 1990 r. o wyborze Prezydenta Rzeczypospolitej Polskiej. 
francuskiej brzmi ono: de la part du condamné. By nie zmieniać sensu Przykład 3: zdania powinno się to przetłumaczyć na język polski jako: przez skazanego.

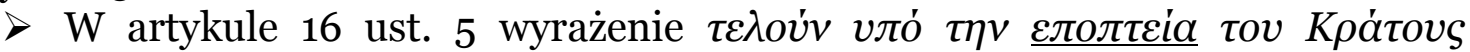
zostało przetłumaczone jako znajduja się pod opieka państwa, ponieważ słowo tutelle użyte w wersji francuskiej (se trouvent sous la tutelle de l'État) oznacza zarówno opiekę, jak i kontrolę ${ }^{13}$. Jednak w oparciu o wersję oryginalną wyrażenie to powinno zostać przetłumaczone następująco: podlegaja kontroli ze strony państwa.

Przykład 4:

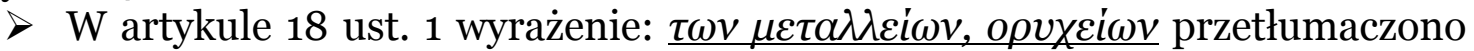
jako kopalnie, kamieniotomy, zgodnie $\mathrm{z}$ wersją francuską, $\mathrm{w}$ której wyrażenie to brzmi: des mines, des carrières. Tymczasem w języku greckim

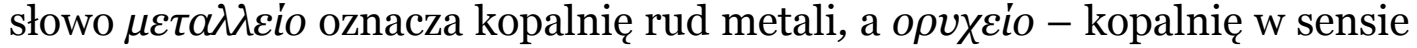
ogólnym ${ }^{14}$, dlatego wyrażenie to powinno brzmieć: kopalnie, $w$ tym rud metali.

Przykład 5:

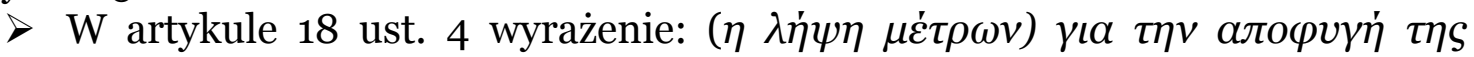

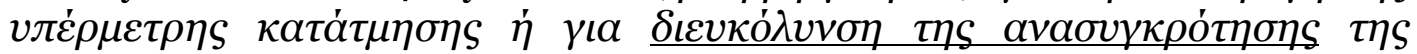

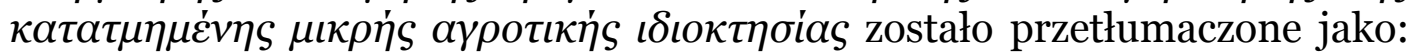
(stosowanie odpowiednich środków) zapobiegających rozdrabnianiu wtasności rolnej oraz sprzyjajacych jej wzmocnieniu. Tymczasem powinno to zostać przetłumaczone następująco: (stosowanie środków) zapobiegajacych nadmiernemu rozdrabnianiu wlasności rolnej lub ulatwiajacych jej restrukturyzacje ( $\mathrm{w}$ wersji francuskiej: la prise de mesures destinées à éviter le morcellement excessif des petites propriétés agricoles ou a faciliter leur reconstitution).

Przykład 6:

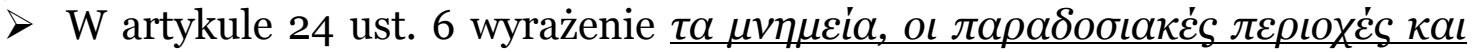

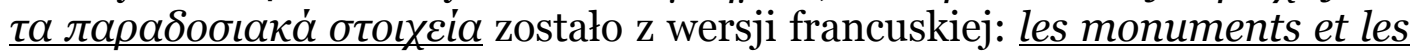
sites et éléments traditionnels przetlumaczone na język polski jako: pomniki $i$ miejsca historyczne oraz ich otoczenie. Według słownika francusko - polskiego 15 słowo monument ma dwa znaczenia: pomnik i zabytek. W kontekście tlumaczonego tu wyrażenia bardziej poprawne wydaje się słowo o szerszym znaczeniu, tj. zabytek. Ponadto, wyrażenie w

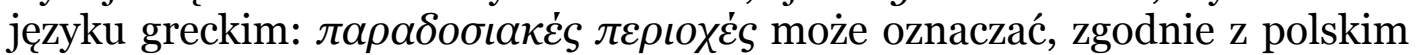

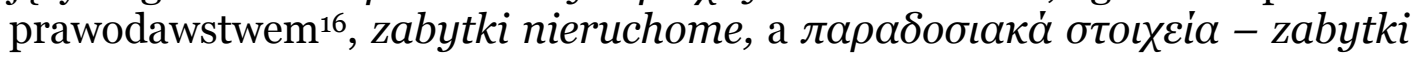
ruchome. W konsekwencji uważam, że poprawne tłumaczenie całego wyrażenia powinno brzmieć następująco: zabytki nieruchome i ruchome. Przykład 7:

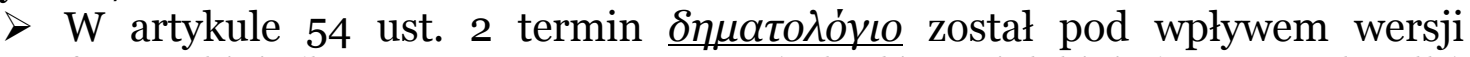
francuskiej (les registres municipaux), bądź angielskiej (municipal rolls) przetłumaczony jako miejskie rejestry. Tymczasem zgodnie z greckim

${ }_{13}$ Wielki słownik francusko-polski (1996)

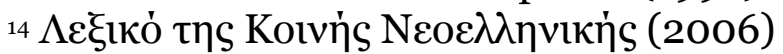

${ }^{15}$ Wielki słownik francusko - polski (1996)

${ }_{16}$ Ustawa z dnia 23 lipca 2003 r. o ochronie zabytków i opiece nad zabytkami. 


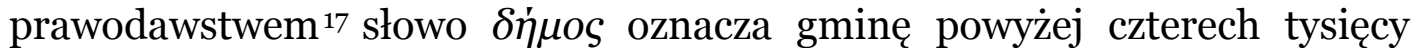
mieszkańców, której siedzibą może być zarówno miasto, jak i wieś. Zatem w tym przypadku za bardziej poprawne można uznać następujące tłumaczenie: gminne rejestry.

Przykład 8:

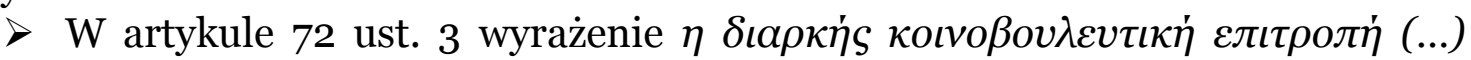

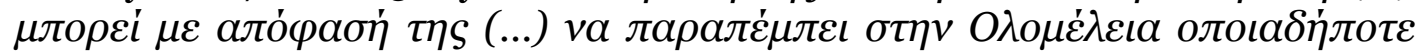

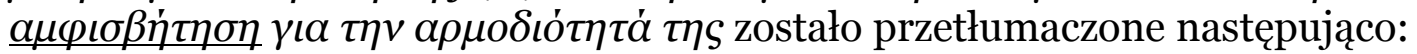
stała komisja parlamentarna (...) ma prawo zdecydować (...) o przekazaniu Zgromadzeniu Plenarnemu wszelkich zarzutów dotyczacych jej kompetencji (choć $\mathrm{w}$ wersji francuskiej wyrażenie to brzmi: la commission parlementaire permanente (..) peut (...) renvoyer à l'assemblée plénière toute contestation concernant sa compétence). Moim zdaniem tłumaczenie tego wyrażenia na język polski powinno brzmieć następująco: stała komisja parlamentarna (...) może zdecydować (...) o przekazaniu Zgromadzeniu Plenarnemu wszelkich watpliwości dotyczacych jej kompetencji.

Przykład 9:

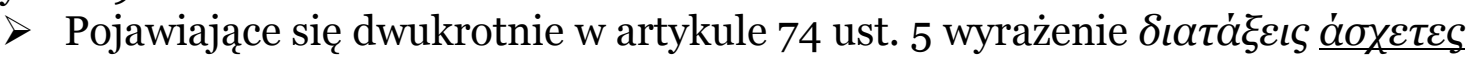

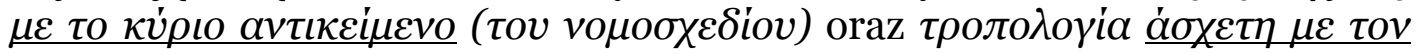

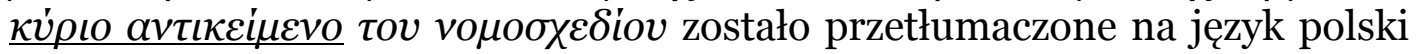
na dwa różne sposoby:

a) przepisy nieodnoszace się do podstawowego celu ustawy,

b) (poprawki, które) nie maja związku z zasadniczym przedmiotem projektu ustawy,

choć $\mathrm{w}$ przekładzie francuskim tłumacze w obu przypadkach zastosowali wyrażenie sans rapport avec l'objet principal, a w przekładzie angielskim: not related to its main subject matter. Uważam, że spośród zacytowanych powyżej tłumaczeń, pierwsze jest błędne. Jego przekład, dokonany na przykładzie drugiego, poprawnego tłumaczenia, powinien brzmieć następująco: przepisy nie mające związku z zasadniczym przedmiotem projektu ustawy.

Przykład 10:

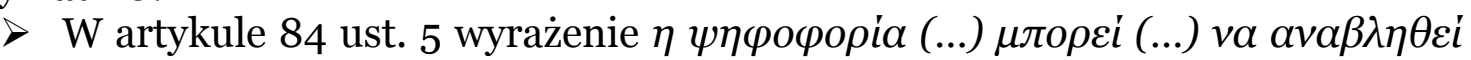

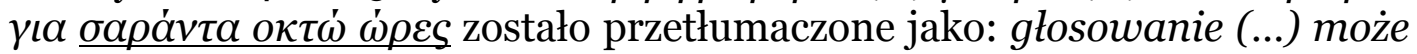
(...) zostać odłożone o 24 godziny, podczas gdy powinno ono brzmieć następująco: głosowanie (...) może (...) zostać odłożone o 48 godzin. Błędu tego nie można wytłumaczyć faktem, iż tekst konstytucji nie był tłumaczony z greckiego oryginału, gdyż zarówno w jego wersji francuskiej (le scrutin (...) peut (...) être reporté de quarante-huit heures), jak i w wersji angielskiej (the vote (...) may (...) be postponed for forty-eight hours) takiego błędu nie popełniono.

Przykład 11:

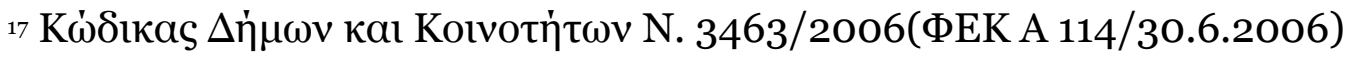




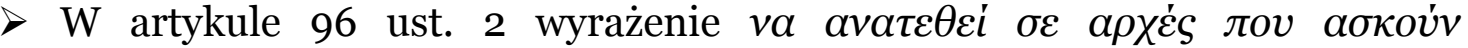

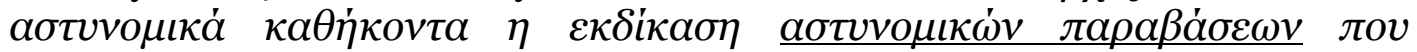

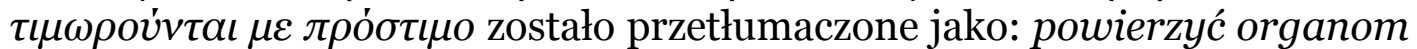
wykonujacym zadania policji rozpatrywanie wykroczeń policji karanych grzywną, zapewne pod wpływem wersji francuskiej (confier à des autorités assumant des fonctions de police le jugement des contraventions de police punies d'amende). Taki przekład sugeruje, że to policja popełnia karane grzywną wykroczenia. Aby uniknąć zbędnych wątpliwości, powinno się owo wyrażenie przetłumaczyć zgodnie z greckim oryginałem: powierzyć organom wykonujacym zadania policji rozpatrywanie wykroczeń policyjnych karanych grzywna.

Przykład 12:

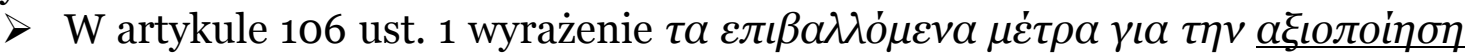

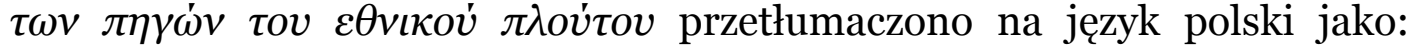
środki niezbędne dla rozwoju źródet bogactwa narodowego, podczas gdy powinno się je przełożyć następująco: środki niezbędne dla wykorzystania źródet bogactwa narodowego. Błędu tego nie można tłumaczyć nieścisłościami w wersji francuskiej, w której wyrażenie to zostało przetłumaczone poprawnie (les mesures nécessaires pour la mise en valeur des sources de richesse national). Można więc założyć, że przekładając ten fragment tłumacze oparli się na wersji angielskiej (all measures necessary to develop sources of national health), zawierającej polisemiczny czasownik to develop, który na język polski tłumaczy się zarówno jako rozwijać, jak i wykorzystywać ${ }^{18}$. Błąd ten został powtórzony w ust. 3 tego samego artykułu.

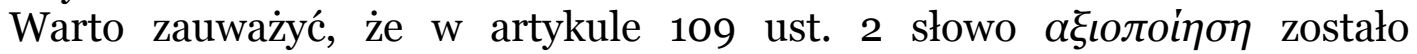
poprawnie przetłumaczone jako: wykorzystanie.

- Na potrzeby analizy przekładu greckiej konstytucji na język polski wyodrębniłam $\mathrm{z}$ kategorii sensu fałszywego osobną grupę, do której zaliczyłam błędy w wyborze środków językowych wyrażających modalność. Za podstawę do ich analizy uznałam artykuł A. Matulewskiej i K. Gortych Translacyjne problemy wyrażania modalności deontycznej $w$ tekstach aktów normatywnych $w$ języku polskim, angielskim i greckim (Matulewska, Gortych 2009: 77-78), w którym autorki dokonały zestawienia wszystkich środków językowych wyrażających modalność deontyczną, stosowanych w greckich, cypryjskich, polskich oraz angielskich aktach normatywnych.

Przykład 1:

$>\mathrm{W}$ artykule 6 ust. 4 fragment $\delta \varepsilon v \mu \pi о \rho \varepsilon i$ $v \alpha v \pi \varepsilon \rho \beta \varepsilon i$, który wyraża zakaz, został przetłumaczony jako: nie powinien przekraczać zamiast: nie może przekraczać.

Warto zauważyć, że w wersji francuskiej brzmi to: ne doit pas excéder, a w Przykład 2: wersji angielskiej: may not exceed, co w obu przypadkach wyraża zakaz.

${ }_{18}$ Słownik angielsko - polski Collins (2002) 


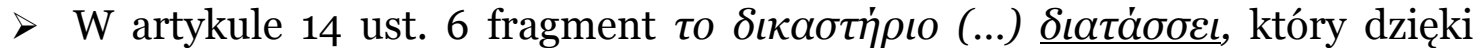
użyciu czasownika w czasie teraźniejszym, trybie dokonanym wyraża nakaz (także w wersji francuskiej: le tribunal décide; $\mathrm{w}$ wersji angielskiej brzmi to: the court shall order), przetłumaczono na: sqd może orzec, co wyraża dozwolenie. Prawidłowe tłumaczenie tego fragmentu na język polski brzmi następująco: sq̨d orzeka.

Przykład 3:

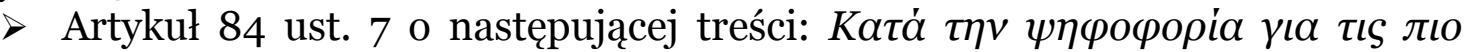

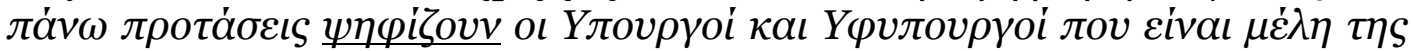
Bov $\lambda \eta^{\prime}$ s przetłumaczono na język polski jako: Ministrowie $i$ sekretarze stanu będacy czlonkami Izby Deputowanych moga brać udział $w$ glosowaniach nad powyższymi wnioskami (chociaż wersja francuska tego zdania brzmi: Les ministres et les secrétaires d'État qui sont membres de la Chambre des députés votent sur les questions et motions ci-dessus, a wersja angielska: Ministers and Undersecretaries who are Members of Parliament shall vote on the above motions).

Oryginalne zdanie wyraża nakaz poprzez użycie czasownika w czasie teraźniejszym i trybie dokonanym, natomiast jego przekład na język polski wyraża dozwolenie. Aby nie zmieniać znaczenia oryginału, zdanie to powinno zostać przetłumaczone następująco: Ministrowie i sekretarze stanu będący czlonkami Parlamentu biora udziat $w$ glosowaniach nad powyższymi wnioskami.

- Sens przeciwny (znaczenie przeciwne) polega na przypisaniu pewnemu fragmentowi tekstu źródłowego znaczenia przeciwnego niż to, które chciał wyrazić autor, co zmienia zupełnie jego intencję. Ta nieprawidłowość może być spowodowana błędną interpretacją lub brakiem wiedzy tłumacza i jest Przykład 1: poważniejszym błędem niż sens fałszywy, ale mniej groźnym niż nonsens.

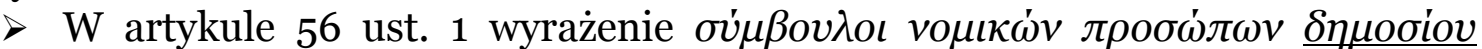
Sikaiov zostało przetłumaczone jako: doradcy osób prawnych prawa prywatnego, chociaż wersja francuska (conseillers mandatés de personnes morales de droit public) oraz wersja angielska (executive directors of public law legal persons) są zgodne z greckim oryginałem. Prawidłowa wersja tego tłumaczenia na język polski brzmi: doradcy osób prawnych prawa publicznego.

Warto zauważyć, że w ustępie 3 artykułu 56 to samo wyrażenie zostało przetłumaczone poprawnie.

Przykład 2:

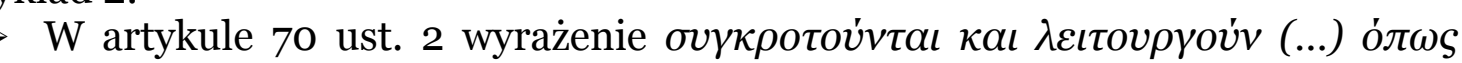

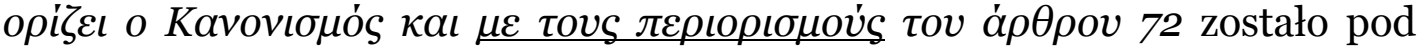
wpływem wersji francuskiej (sont constituées et fonctionnent (...) comme en dispose le Règlement et sans préjudice des restrictions prévues à l'article 72) przetlumaczone jako: sq powotywane $i$ funkcjonuja (...) zgodnie $z$ postanowieniami Regulaminu i bez uszczerbku dla ograniczeń, o których mowa $w$ art. 72. Zgodnie z sensem greckiego oryginału (który zachowano $\mathrm{w}$ wersji angielskiej: are established and function (...) as specified by the Standing Orders and subject to the restrictions of article 72) oraz wedlug zasad polskiego języka prawnego tłumaczenie tego wyrażenia powinno 
brzmieć następująco: sq powotywane $i$ funkcjonują (...) zgodnie $z$ postanowieniami Regulaminu i z zastrzeżeniem art. 72.

- Nonsens polega na przypisaniu jakiemuś fragmentowi tekstu źródłowego na tyle zmienionego sensu, że w efekcie tłumacz otrzymuje sformułowanie kompletnie absurdalne. Jest to najpoważniejszy błąd tłumaczeniowy i wynika $\mathrm{z}$ wadliwej interpretacji lub braku myślenia ze strony tłumacza (w analizowanym tekście przekładu nie odnalazłam ani jednego przykładu nonsensu) (Delisle, Lee-Jahnke, Cormier 2004: 68, 128, 130).

Analizując tekst tłumaczenia konstytucji Grecji na język polski odnalazłam także kilka przykładów błędów terminologicznych, które nie zaliczają się do żadnej z wyszczególnionych powyżej kategorii błędów (do tego typu nieprawidłowości należy między innymi brak spójności terminologicznej).

Przykład 1:

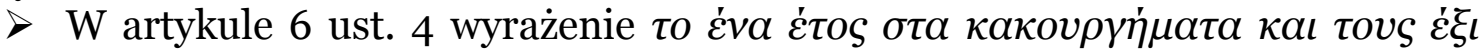

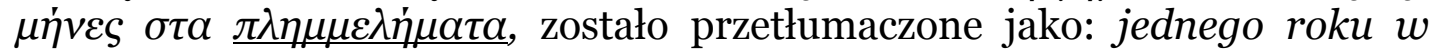
przypadku zbrodni i 6 miesięcy $w$ przypadku przestepstwa. Według art.7 §1 polskiego Kodeksu Karnego ${ }^{19}$ przestępstwo jest zbrodnią albo występkiem, dlatego tłumaczenie tego wyrażenia powinno brzmieć: jednego roku $w$ przypadku zbrodni i 6 miesięcy $w$ przypadku występku. Błąd ten wynika $\mathrm{z}$ użycia języka potocznego zamiast specjalistycznego języka prawnego.

To rozróżnienie sprawiło trudność twórcom polskiej wersji konstytucji Grecji również $\mathrm{w}$ artykule 97 ust. 2, gdzie zdanie $M \varepsilon$ vó $\mu о \mu \pi о \rho \varepsilon i ́ ~ v \alpha$

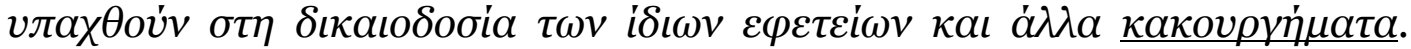
zostało przetłumaczone jako: Ustawa może przekazać także rozpatrywanie innych przestepstw do kompetencji Sądu Apelacyjnego. Zgodnie z polską i grecką terminologią, zdanie to powinno brzmieć: Ustawa może przekazać Przykład 2: także rozpatrywanie innych zbrodni do kompetencji Sądu Apelacyjnego.

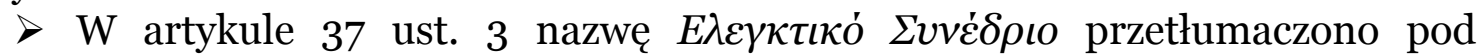
wpływem francuskiego Cour des comptes jako: Izba Obrachunkowa. Tymczasem w polskiej rzeczywistości prawnej organem o podobnych kompetencjach jest Najwyższa Izba Kontroli i takie tłumaczenie greckiego terminu byłoby właściwe, w przypadku zastosowania ekwiwalencji konotacyjnej. Jednak, jako że w całym tekście tłumaczenia stosowano się do zasad ekwiwalencji denotacyjnej, sugerowałabym użycie terminu Izba Kontroli, ponieważ oddaje on sens greckiego oryginału lepiej niż pierwotne

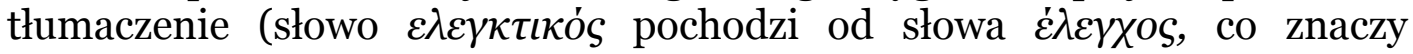
kontrola).

Przykład 3:

Błąd ten powtórzono wielokrotnie w polskim przekładzie konstytucji.

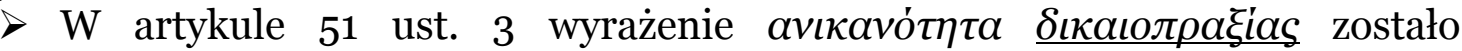
przetłumaczone jako: niezdolność do czynności cywilnych. Tymczasem w polskim prawodawstwie, (według tytułu II, działu I, rozdziału I polskiego

19 Ustawa z dnia 6 czerwca 1997 r. - Kodeks karny. 
Kodeksu Cywilnego ${ }^{20}$ ) stan ten nazywa się niezdolnościq do czynności prawnych.

Błąd ten nie mógł być spowodowany nieścisłościami w wersji francuskiej (incapacité d'exercice), ani w wersji angielskiej (legal incapacity).

Przykład 4:

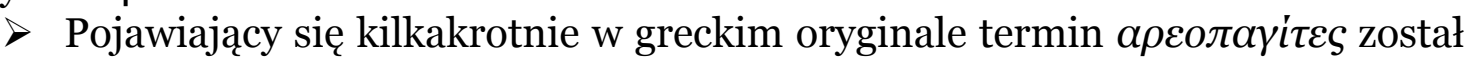
przetłumaczony na język polski na dwa sposoby:

a) w artykule 87 ust. 3 oraz w artykule 91 ust. 2 jako: radcy $S q d u$ Kasacyjnego (zapewne pod wpływem wersji francuskiej: conseillers à la Cour de cassation),

b) w artykule 90 ust. 2, w artykule 91 ust. 1, w artykule 99 ust. 1 oraz w artykule 100 ust. 2 jako: sẹdziowie Sądu Kasacyjnego.

Tłumacze popełnili w tym przypadku rażący błąd, który polega na braku spójności terminologicznej. Według słownika języka greckiego ${ }^{21}$ definicja

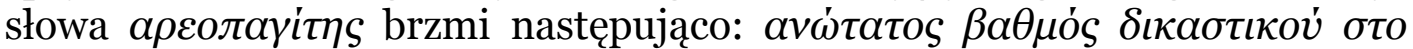

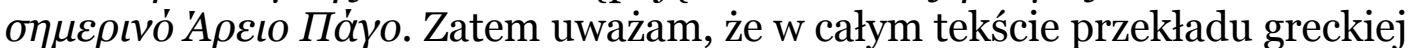
konstytucji na język polski tłumacze powinni używać rozwiązania zacytowanego w drugim z powyższych podpunktów.

Do ostatniej kategorii błędów tłumaczeniowych, zgodnie z klasyfikacją sporządzona przez A. Pisarską i T. Tomaszkiewicz, należy niezgodność informacji znaczących w stosunku do oryginału, która może polegać na zbyt małej lub zbyt dużej ilości informacji w przekładzie (Pisarska, Tomaszkiewicz 1998: 162-163). Do pierwszej grupy zaliczają się:

- podtłumaczenie, kiedy tłumacz nie zastosuje w przekładzie, tam gdzie jest to potrzebne do właściwej interpretacji sensu tekstu źródłowego, odpowiedniego rozwinięcia lub kompensacji ( $\mathrm{w}$ analizowanym przekładzie nie odnalazłam przykładów błędów tego typu),

- opuszczenie, kiedy tłumacz bez wyraźnych przyczyn opuszcza w tekście docelowym jakiś istotny z punktu widzenia przekazu informacji fragment tekstu źródłowego (Delisle, Lee-Jahnke, Cormier 2004: 72, 74).

Przykład 1:

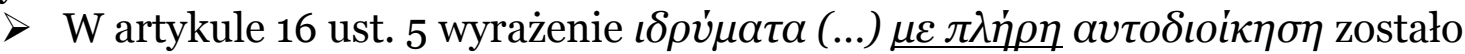
przetłumaczone jako: samorzqdne jednostki. Zgodnie zarówno $\mathrm{z}$ wersją grecką, francuską (établissements pleinement décentralisés), jak i angielską (institutions which are fully self-governed) powinno się to przetlumaczyć jako: jednostki w petni samorzadne.

Przykład 2:

$>\mathrm{W}$ thumaczeniu na język polski fragmentu artykułu 18 ust. 8: $\delta \varepsilon v$

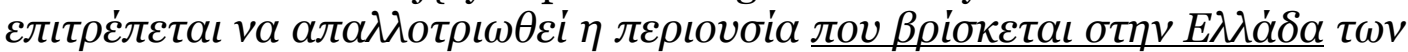

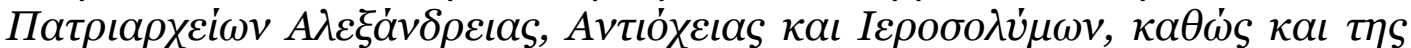

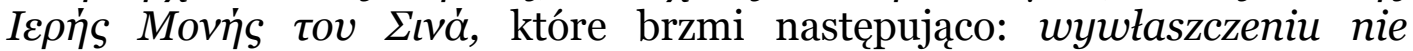

${ }_{20}$ Ustawa z dnia 23 kwietnia 1964 r. - Kodeks cywilny.

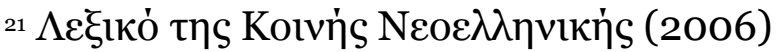


podlegają dobra patriarchatów: Aleksandrii, Antiochii $i$ Jerozolimy oraz Świętego Klasztoru na Synaju opuszczono istotną informację o tym, że dobra te znajdują się w Grecji, choć jest ona obecna w wersji francuskiej (ne sont pas susceptibles d'expropriation les biens en Grèce des Patriarcats d'Alexandrie, d'Antioche et de Jérusalem, ainsi que ceux du Saint Monastère du Sinaï) oraz angielskiej (the property in Greece of the Patriarchates of Alexandria, Antiocheia and Jerusalem and that of the Holy Monastery of Mount Sinai cannot be subject to expropriation). Zdanie to powinno zatem brzmieć $\mathrm{w}$ języku polskim następująco: wywlaszczeniu nie podlegaja znajdujace sie $w$ Grecji dobra patriarchatów: Aleksandrii, Antiochii i Jerozolimy oraz Świętego Klasztoru na Synaju.

Przykład 3:

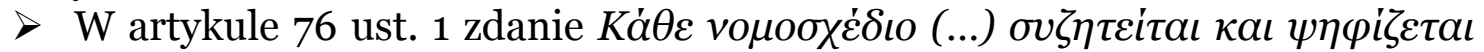

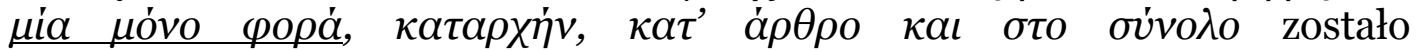
przetłumaczone na język polski następująco: Każdy projekt ustawy jest rozpatrywany $i$ poddawany pod glosowanie kolejno $w$ przedmiocie zatożeń, artykut po artykule $i$ jako całość. W zdaniu tym brakuje informacji, o tym że rozpatrywanie projektu ustawy i głosowanie nad nim odbywa się tylko raz, choć informacja ta jest zachowana w wersji francuskiej (Tout projet (...) sont discutés et votés une seule fois, dans le principe, par article et sur l'ensemble) oraz angielskiej (Every Bill and every law proposal shall be debated and voted on once in principle, by article and as a whole).

Zatem prawidłowe tłumaczenie tego zdania na język polski powinno brzmieć: Każdy projekt ustawy jest rozpatrywany i poddawany pod glosowanie tylko raz, kolejno $w$ przedmiocie założeń, artykut po artykule $i$ jako całość.

Przykład 4:

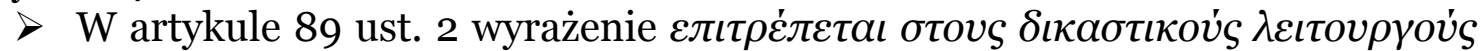

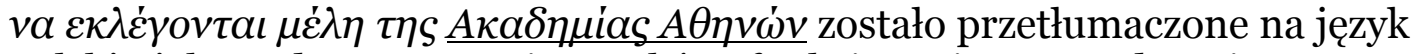
polski jako: dopuszcza się wybór funkcjonariuszy sq̨downictwa na czlonków Akademii. Polska wersja, w przeciwieństwie do greckiego oryginału oraz do wersji angielskiej (magistrates may be elected members of the Athens Academy) nie uściśla, o jakiej Akademii mowa. Błąd ten został popełniony już przez twórców wersji francuskiej (est permise l'élection des magistrats comme membres de l'Académie) i powtórzony przez polskich tłumaczy. Aby przekazać cały sens oryginału, wyrażenie to powinno brzmieć następująco: dopuszcza się wybór funkcjonariuszy sądownictwa na czlonków Akademii Ateńskiej.

Przykład 5:

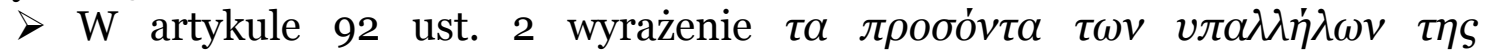

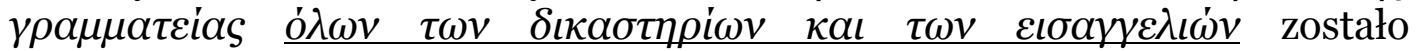
następująco przetłumaczone na język polski: kwalifikacje pracowników kancelarii wszystkich typów. Tymczasem zdanie to, zgodnie z oryginałem oraz wersją francuską (les qualités requises pour les employés du greffe de tous les tribunaux et parquets), powinno brzmieć: kwalifikacje pracowników kancelarii wszystkich typów sadów $i$ prokuratur. Sprecyzowanie rodzaju kancelarii, o którym mowa $\mathrm{w}$ artykule jest 
niezbędne, jako że w języku polskim występuje wiele innych ich typów (np. adwokacka, radców prawnych).

Do drugiej grupy należą:

- nadtłumaczenie, kiedy tłumacz dosłownie wyraża w tekście docelowym pewne elementy, które powinny pozostać domyślne ( $\mathrm{w}$ analizowanym przekładzie nie odnalazłam błędów tego typu),

- uzupełnienie, kiedy tłumacz w sposób nieuzasadniony dodaje w tekście docelowym pewne zbędne informacje lub efekty stylistyczne, które były nieobecne w tekście źródłowym (Delisle, Lee-Jahnke, Cormier 2004: 63, 113).

Przykład 1:

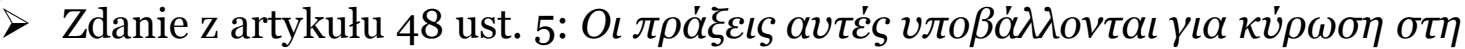

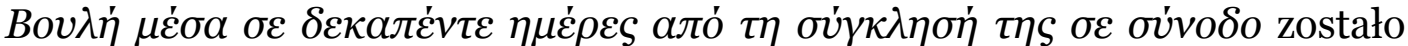
na język polski przetłumaczone następująco: Akty te sa przedstawiane Izbie Deputowanych do zatwierdzenia $w$ ciagu 15 dni od dnia ich promulgacji lub od dnia zebrania się Izby Deputowanych na sesji. Ponownie błąd uzupełnienia popełnili twórcy wersji francuskiej (Ces actes sont soumis à la Chambre des députés pour ratification dans les quinze jours à compter de leur édiction ou de la convocation de la Chambre en session) oraz angielskiej (Those acts shall be submitted to Parliament for ratification within fifteen days of their issuance or of the convocation of Parliament in session), a w konsekwencji został on powtórzony w polskim tłumaczeniu. By było poprawne, zdanie to powinno brzmieć: Akty te sq przedstawiane Parlamentowi do zatwierdzenia $w$ ciagu 15 dni od dnia zebrania się Parlamentu na sesji.

Przykład 2:

$>\mathrm{W}$ przekładzie na język polski artykułu 48 ust. 2 pojawia się zdanie, którego nie ma w greckim oryginale: Ustawa dotyczaca stanu wyjatkowego nie może być zmieniana $w$ czasie jego obowiązywania. Najprawdopodobniej błąd uzupełnienia popełnili już twórcy wersji francuskiej, w której zdanie to brzmi następująco: La loi sur l'état de siège ne peut être modifiée durant son application, i został on powtórzony przez polskich tłumaczy.

Przykład 3:

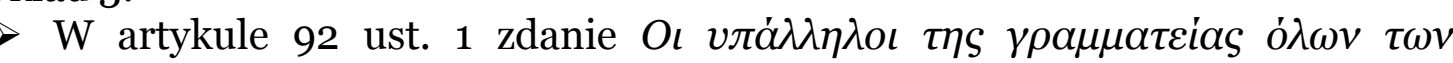

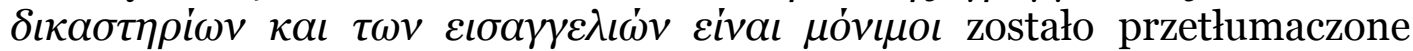
jako: Pracownicy kancelarii wszystkich typów sądów i prokuratur sa nieusuwalni, dopóki istnieja ich stanowiska. Ostatnia, zaznaczona część tego zdania nie pojawia się $\mathrm{w}$ oryginale. Została ona dodana najprawdopodobniej pod wpływem wersji francuskiej (Les employés du greffe de tous les tribunaux et parquets sont des fonctionnaires qui restent en service tant que leurs emplois existent), ponieważ nie pojawia się ona w wersji angielskiej (The civil servants of all courts' offices and prosecutors' offices shall be permanent).

W wersji polskiej zdanie to powinno brzmieć: Pracownicy kancelarii wszystkich typów sądów i prokuratur są nieusuwalni. 


\subsection{Błędy językowe}

Obok błędów tłumaczeniowych w tekście przekładu mogą występować również błędy, zwane przez wielu teoretyków przekładu (m.in. przez A. Pisarską i T. Tomaszkiewicz) językowymi. Wynikają one z braku znajomości przez tłumacza elementów języka docelowego, niedostatecznego opanowania jego słownictwa lub gramatyki oraz niezastosowania technik redagowania tekstu.

$\mathrm{Na}$ potrzeby niniejszego artykułu, zastosowałam klasyfikację błędów sporządzoną przez P. Nowak podczas analizy nieścisłości w przekładzie unijnych aktów normatywnych. Rozróżniła ona następujące kategorie błędów:

$>$ błędy ortograficzne (niewłaściwe użycie wielkich i małych liter, niewłaściwa litera w zapisie),

> błędy interpunkcyjne (brak znaku interpunkcyjnego, zbędne użycie znaku interpunkcyjnego, użycie niewłaściwego znaku interpunkcyjnego),

> błędy stylistyczne (użycie języka prawniczego zamiast prawnego, użycie języka potocznego zamiast specjalistycznego, użycie języka literackiego zamiast specjalistycznego),

> błędy gramatyczne: fleksyjne (wybór niewłaściwej postaci tematu fleksyjnego, wybór niewłaściwej końcówki fleksyjnej) i składniowe (zakłócenie związku rządu i zgody, błędy w używaniu przyimków, konstrukcje niepoprawne pod względem szyku),

> błędy leksykalne (frazeologiczne, neologizmy leksykalne, zmiana znaczenia),

> pozostałe błędy (dodanie, opuszczenie, nonsens, inne przypadki zmiany znaczenia) (Nowak 2006: 174-189).

Stosując powyższą klasyfikację wyłącznie do błędów językowych, odnalazłam w analizowanym przekładzie następujące kategorie błędów:

- Błędy ortograficzne:

Przykład 1:

$>$ Niewłaściwa litera w zapisie: $\mathrm{W}$ artykule 47 ust. 3 wyrażenie $\mu \varepsilon$ vó $\mu о$ лоv

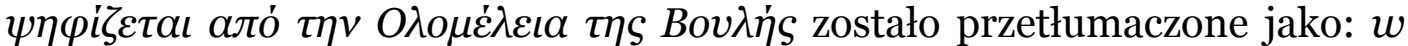
drodze ustawy uchwalonej na posiedzeniu planarnym Izby Deputowanych. Tłumaczenie to powinno brzmieć (po równoczesnym poprawieniu omówionego powyżej błędu, którym jest użycie sformułowania Izba Deputowanych): $w$ drodze ustawy uchwalonej na posiedzeniu plenarnym Parlamentu.

Błąd ten powtarza się kilkakrotnie w analizowanym tu przekładzie.

- Błędy stylistyczne:

Przykład 1:

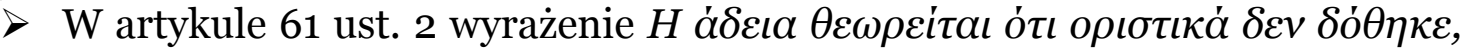

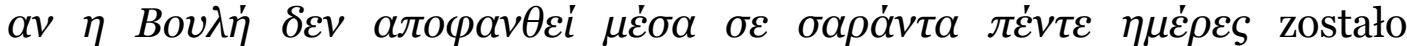
przetłumaczone następująco: Uznaje się, że wyrażenie zgody zostało ostatecznie odmówione, jeżeli Izba Deputowanych nie wypowie się $w$ ciagu 45 dni. Prawidłowa dla języka polskiego kolokacja brzmi: Uznaje się, że ostatecznie odmówiono wyrażenia zgody, jeżeli Parlament nie wypowie się $w$ ciagu 45 dni.

- Błędy gramatyczne - fleksyjne: 
Przykład 1:

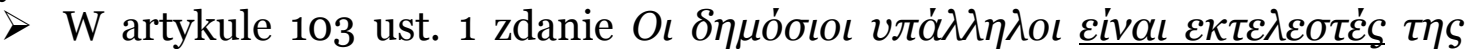

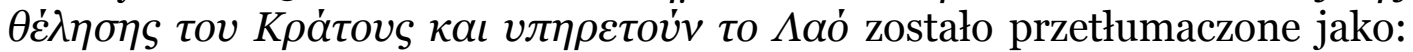
Funkcjonariusze publiczni wykonaja wole państwa i stuża ludowi. W pierwszej części tego zdania czasownik wyraża czas przyszły dokonany, w przeciwieństwie do czasownika w drugiej części zdania, który, zgodnie z greckim oryginałem wyraża czas teraźniejszy. Prawidłowy przekład tego zdania powinien brzmieć następująco: Funkcjonariusze publiczni wykonuja wolę państwa i stużą ludowi.

- Błędy gramatyczne - składniowe:

Przykład 1:

> Zakłócenie związku rządu: W deklaracji wyjaśniającej do art. 4 wyrażenie

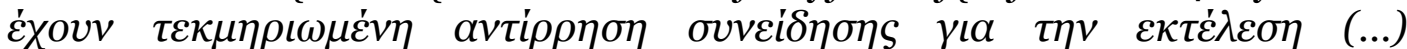

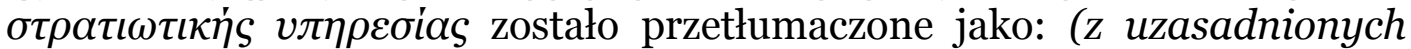
względów sumienia) wyrażaja sprzeciw wobec odbywaniu stużby wojskowej. Zgodnie z regułami składni języka polskiego wyrażenie wyrażać sprzeciw wobec czegoś wymaga użycia dopełniacza, a nie celownika. W konsekwencji wyrażenie to powinno brzmieć wyrażaja sprzeciw wobec odbywania stużby wojskowej.

Przykład 2:

$>$ Konstrukcja niepoprawna pod względem szyku: W artykule 7 ust. 4 zdanie

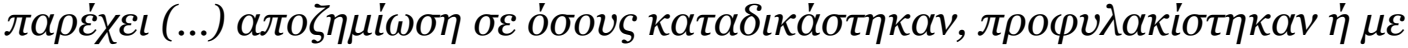

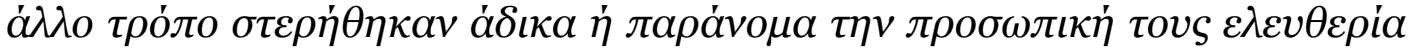
zostało przetłumaczone jako: przyznaje odszkodowania osobom skazanym niesprawiedliwie lub niezgodnie $z$ prawem, więzionym lub $w$ jakikolwiek inny sposób pozbawionym wolności osobistej. Popełniony w tym zdaniu błąd składniowy zmienił jego sens i sprawił, że można je wieloznacznie interpretować. Poprawna wersja tego zdania powinna brzmieć następująco: przyznaje odszkodowania osobom niesprawiedliwie lub niezgodnie $\mathrm{Z}$ prawem skazanym, więzionym lub $w$ jakikolwiek inny sposób pozbawionym wolności osobistej.

Przykład 3:

$>$ Błąd w używaniu przyimków: W artykule 44 ust. 1 wyrażenie $\alpha v \delta \varepsilon v$

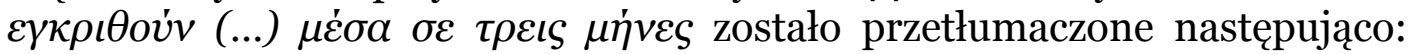
jeżeli nie zostana (...) zatwierdzone ciagu 3 miesięcy. Tymczasem powinno ono brzmieć: jeżeli nie zostana (...) zatwierdzone $w$ ciagu 3 miesięcy.

Przykład 4:

$>$ Zastosowanie nieodpowiedniej strony czasownika: W artykule 51 ust. 4

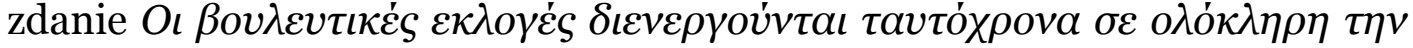

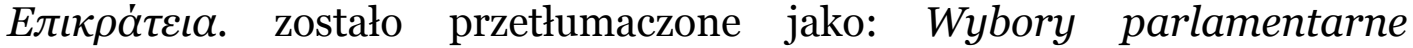
odbywaja jednocześnie na terytorium całego kraju. Według Słownika Języka Polskiego PWN22, w tym znaczeniu czasownik odbyć wymaga zaimka się, zatem tłumaczenie to powinno brzmieć następująco: Wybory parlamentarne odbywaja się jednocześnie na terytorium całego kraju.

${ }^{22}$ Słownik Języka Polskiego PWN (1999) 
Przykład 5:

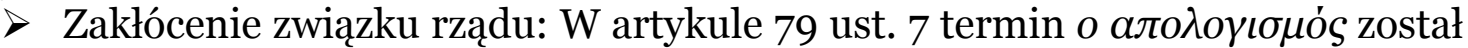
przetłumaczony następująco: ustawa o wykonania budżetu. W gramatyce języka polskiego na pytania o kim? o czym? odpowiada miejscownik ${ }^{23}$, zatem prawidłowe tłumaczenie tego terminu brzmi: ustawa o wykonaniu budżetu.

\section{Podsumowanie}

Najważniejszym wnioskiem, który nasuwa się w wyniku przeprowadzenia analizy przekładu greckiej konstytucji na język polski jest stwierdzenie, iż tłumaczenie to nie zawierałoby tak licznych błędów, gdyby tworzący je tłumacze oparli się na jej oryginalnej - greckiej wersji. Porównanie greckiej i polskiej wersji konstytucji z tekstami w języku francuskim i języku angielskim, które stanowiły podstawę przekładu wykazało, iż większości błędów pojawiających się w tekście polskim można było uniknąć, tłumacząc konstytucję bezpośrednio z języka greckiego.

W czasach coraz bardziej intensywnej integracji europejskiej znaczenie tłumaczenia, a w szczególności przekładu tekstów prawnych i prawniczych, gwałtownie wzrasta. Jest sprawą oczywistą, że teksty te powinny być przekładane przez wykwalifikowanych tłumaczy, sprawnie posługujących się językiem prawa, ponieważ błąd popełniony w tłumaczeniu tego typu tekstu może nieść za sobą bardzo poważne konsekwencje. Jednak, jeśli nawet najlepszy tłumacz przekłada tekst prawny lub prawniczy nie bezpośrednio z oryginału, ale opierając się na jego uprzednio przetłumaczonej na inny język wersji, trudno jest mu uniknąć błędów.

Myślę, że wyniki badań, które przeprowadziłam są poważnym argumentem na uzasadnienie tezy, iż teksty wszelkiego rodzaju, a w szczególności teksty prawne i prawnicze, powinny być tłumaczone wyłącznie bezpośrednio z oryginału. Oby jak najszybciej takie podejście stało się standardem w praktyce translatorskiej.

Mam nadzieję, że w przypadku, gdy Wydawnictwo Sejmowe podejmie decyzję o druku trzeciego wydania Konstytucji Grecji, z uwzględnieniem poprawek będących skutkiem nowelizacji z maja 2008 roku, wzięte pod uwagę zostaną również niezbędne poprawki rozwiązań translacyjnych i językowych, o których traktuje niniejszy artykuł. 
Natalia Ciesielczyk: Analiza problemów tlumaczeniowych przekładu konstytucji Grecji na język polski.

\section{Bibliografia}

\section{Teksty źródłowe}

Konstytucja Grecji. 2005. Tłumaczenie: G. i W. Uliccy, B. Zdaniuk. Warszawa: Wydawnictwo Sejmowe.

Constitution de la Grèce: http://www.parliament.gr/english/pdf/oo1180\%2ogalliko.pdf

The constitution of Greece: http://www.parliament.gr/english/pdf/oo1156\%20aggliko.pdf

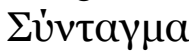

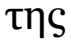

E $\lambda \lambda \dot{\alpha} \delta a$ : $^{-}$ http://www.parliament.gr/pdf/syntagmaHanatheoritikiVouli.pdf

\section{Literatura przedmiotu}

Bonarek, J., Czekalski, T., Sprawski, S., Turlej, S. 2005. Historia Grecji. Kraków: Wydawnictwo Literackie.

Brzeziński, A. 2002. Grecja. Warszawa: Wydawnictwo Trio.

Delisle, J., Lee-Jahnke, H., Cormier, M.C. Tłumaczenie: T. Tomaszkiewicz. 2004. Terminologia thumaczenia. Poznań: Wydawnictwo Naukowe UAM.

Jopek-Bosiacka, A. 2006. Przekład prawny i sq̨dowy. Warszawa: Wydawnictwo Naukowe PWN.

Kamiński, J. 2004. System konstytucyjny Grecji. Warszawa: Wydawnictwo Sejmowe.

Lukszyn, J. (red). 1993. Tezaurus terminologii translatorycznej. Warszawa: Wydawnictwo Naukowe PWN.

Manganaras, I. 1996. The qualified legal translator is a lawyer trained in translation, Lingua legis. Czasopismo Polskiego Towarzystwa Ttumaczy Ekonomicznych, Prawniczych i Sądowych TEPIS 4, 13-20.

Matulewska, A., Nowak, P. 2006. Translation Errors and Mistakes in Polish Language Versions of EU Legal Texts, P. Nowak, P. Nowakowski (red). Język, Komunikacja, Informacja. Poznań: Wydawnictwo SORUS, 31-39.

Matulewska, A., Gortych, K. 2009. Translacyjne problemy wyrażania modalności deontycznej w tekstach aktów normatywnych $\mathrm{w}$ języku polskim, angielskim i greckim, A. Mróz, A. Niewiadomski, M. Pawelec (red). Prawo i język. Warszawa: Uniwersytet Warszawski, 65-78.

Nowak, P. 2006. Analiza błędów w przekładzie unijnych aktów normatywnych na przykładzie Council Regulation (EC) no 1346/2000 of 29 May 2000 on Insolvency Proceedings, Investigationes Linguisticae XIII, 171-195.

Pieńkos, J. 1999. Podstawy juryslingwistyki. Język $w$ prawie - Prawo $w$ języku. Warszawa: Oficyna Prawnicza MUZA SA.

Pisarska, A., Tomaszkiewicz, T. 1998. Współczesne tendencje przekładoznawcze. Podręcznik dla studentów neofilologii. Poznań: Wydawnictwo Naukowe UAM.

Schroth, P.W. 1986. Legal Translation, The American Journal of Comparative Law.vol. 34 [supplement], 47-66. 


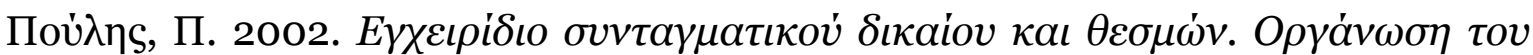

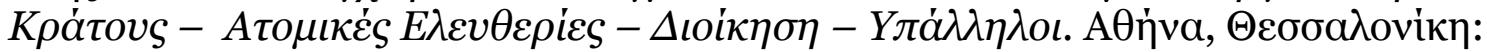

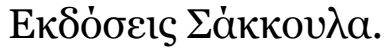

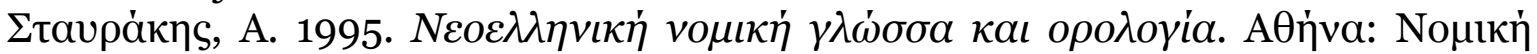
Вı $\beta \lambda_{\iota} \circ \dot{\eta} \kappa \eta$.

\section{Słowniki}

Stownik angielsko - polski Collins. 2002. J. Fisiak (red). Warszawa: Oficyna Wydawnicza Graf-Punkt.

Stownik Języka Polskiego PWN. 1999. M. Szymczak (red). Warszawa: Państwowe Wydawnictwo Naukowe.

Wielki stownik francusko-polski. 1996. S. Ciesielska-Borkowska (red). Warszawa: Wiedza Powszechna.

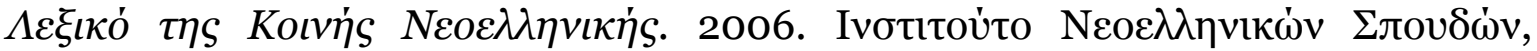

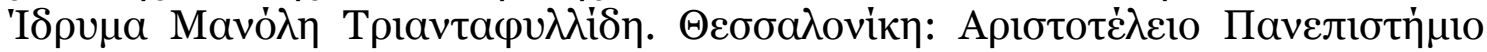

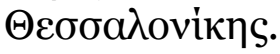

\section{Ustawy}

Ustawa z dnia 23 kwietnia 1964 r. - Kodeks cywilny.

Ustawa z dnia 27 września 1990 r. o wyborze Prezydenta Rzeczypospolitej Polskiej.

Ustawa z dnia 6 czerwca 1997 r. - Kodeks karny.

Ustawa z dnia 6 czerwca 1997 r. - Kodeks karny wykonawczy.

Ustawa z dnia 23 lipca 2003 r. o ochronie zabytków i opiece nad zabytkami.

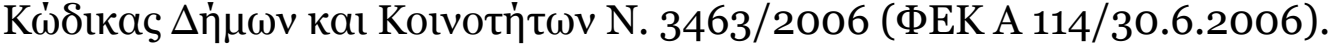

